International Journal of Social Sciences and Humanities
Available online at http://sciencescholar.us/journal/index.php/ijssh
Vol. 5 No. 2, March 2018, pages: 43 55
e-ISSN: 2550-7001, p-ISSN: 2550-701X
http://dx.doi.org/10.29332/ijssh.v2n1.78

\title{
Surya Namaskara Benefits for Physical Health
}

I Gusti Bagus Wirawan ${ }^{a}$

Article history: Received 25 July 2017, Accepted in revised form 28 January 2018, Approved 5 February 2018, Available online 9 February 2018

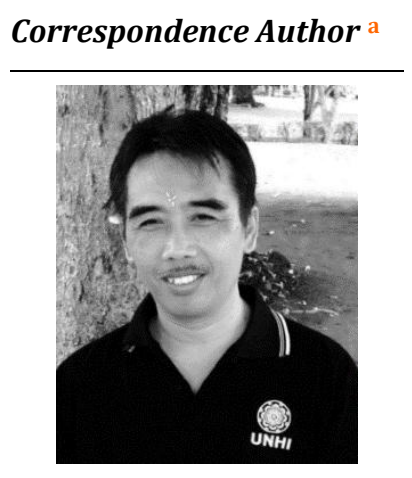

Keywords

Endocrine system;

Lower middle economy;

Pasraman;

Physical health;

Surya namaskara;

\begin{abstract}
Roga (disease) was an ancient problem that exists and so far remains incomplete tackling. Advances in science and technology included the modern medical systems with the various sophistication of the tools were also overwhelmed. The effects of the modern synthetic drugs might leave the chemical impact problems. Considering that, the society become worried about the impact. In addition, the price of the modern medicine was also quite high, difficult to reach by the society who had the ability to the lower middle economy. Based on these considerations, the Pasraman Sri Jagat Amertham, Bitra, Gianyar Regency and UKM Yoga Marga Rahayu, University of Hindu Indonesia observes the traditional health care and treatment system as an alternative way. The system of the treatment and coaching was patient, diligently, and sincere doing the series of Surya Namaskara movement. There were two terms discussed in the present study, i.e. (1) how was the series of Surya Namaskara movement exhibited by Pasraman Sri Jagat Amertham devotees, Bitra Village, Gianyar Regency and the students of UKM Yoga Marga Rahayu, University of Hindu Indonesia; (2) What were the benefits perceived by Pasraman Sri Jagat Amertham, Bitra, Gianyar Regency and UKM Yoga Marga Rahayu, University of Hindu Indonesia on physical health? The methods that were used to discuss the problems included observations and interviews for collecting the data, whereas, the descriptions and interpretations were used in describing, explaining, and analyzing data. Through the ways mentioned above, Surya Namaskara movement consists of the twelve dynamic movements. However, before doing Surya Namaskara movement begins with praying, that was Gayatri Mantran song three times and pranawa $\mathrm{Om}$ as many as five times then do a new stretching (pavanamuktasana). Steady, patient, diligent and sincere performing were series of Surya Namaskara movements could balance the internal organs (human) system primarily related to the respiratory system, circulatory system, digestive system, urinary or urinal system, skin system, nervous system, and endocrine system. The endocrine glands included the pituitary, pineal, thyroid, parathyroid, thymus, adrenal and gonads. With the balance of the internal organs, the healthy physically would be better and the mind would be calm and peaceful.
\end{abstract}

a University of Hindu Indonesia 
e-ISSN : 2550-7001, p-ISSN : 2550-701X ๑ Copyright 2018. The Author. SS Journals Published by Universidad Técnica de Manabí.

This is an open-access article under the CC BY-SA 4.0 license

(https://creativecommons.org/licenses/by-sa/4.0/)

All rights reserved.

\section{Contents}

Abstract

1. Introduction

2. Research Method

3. Results and Analysis

4. Conclusion

Acknowledgements

References

Biography of Authors

\section{Introduction}

On the one hand, the humans in their life ever feel pain or suffering, whether related to physical or mental. Therefore, the disease is an issue for everyone that exist and currently incompletely overcome. An advance in science and technology is included the modern medical systems with the various sophistication of the tools are also overwhelmed. The effects of the modern synthetic drugs may leave chemical impact issues. Regarding it, the society becomes concerned about its impact (Yasa et al: 1). In addition, the cost of the modern medicine is also quite expensive; it is hard for the society which the lower/middle economy level. Based on these considerations, the society is interested in the traditional healthcare and treatment system as an alternative way.

On the other hand, the social change included their lifestyle is an integral part of the modern society life (Atmaja, 2010: 1). The modern lifestyles that tend to the luxury lead more to the fulfillment of the physical and sensual pleasures. This will require more diversity needs to be met and will have an impact on the mindset. If the needs are not met, and the ability absence to control their mind and body may due to mental stress, worry, and eventually become stressful. In order to overcome the issue, many societies miss it by watching to the cinema or nightclub for recreation, sleeping pills and all kinds of the drugs getting the peace and to negate the negative effects of the modern life (Satyananda, 2002: 5). If it happens for a long time can make the mental and physical easy to get a disease.

According to (Wrahaspati Tattwa: 33) stated that there are three types of the disease usually infected to the humans called duhka telu. This happens due to tresna (love) is 'bound' to the karma of 'deeds'. The diseases included, 1) adhyatmika duhka defines the disease that comes from the uncontrollable thoughts, unlike the high ambition, hatred, infatuation, hurt, nerves. According to (Yasa et al. (2011: 2) stated that adhyatmika duhka is a disease due to uncontrollable thoughts, e.g., passionate ambition, acting carelessly because of impetuousness, abusive behavior for being hate and anger, confusion, and a broken heart. 2) daiwika duhka defines is the disease due to the curse of the god (included the curse by the saint, parent, and ancestor). The diseases types experienced unlike being struck by lightning, controlled by the evil spirits, confused, grumpy, not know what is right and wrong, and become unlucky people. 3) bhautika duhka is the disease due to bhuta. Bhuta is a spirited and subtle creature that has a body, like a weapon, poisoned, pierced thorns, snake poison (upas), infected by teluh (magic media), etc., that becomes a disease.

Respecting the above phenomenon, there are several ways can be used by the societies to keep their physical health and avoid them from duhka telu. One of the best and the cheapest ways is patiently and diligently practicing Yoga Asana, namely Surya Namaskara. Surya Namaskara is a practice system that was from prehistoric times when the human is aware of their spiritual power those are reflected in the material universe (Satyananda, 2002: 5).

Surya Namaskara is an integral part of yoga approach and can easily be applied in every day of life. It only takes about 5 (five) to 15 (fifteen) minutes for practicing to get quick and useful results. Therefore, 
Surya Namaskara is very suitable for active people, e.g., entrepreneurs, housewives, students who will face an examination or scientists who spend most of their time thinking (Satyananda 2005: 2).

Recently, Yoga Asana, especially, Surya Namaskara and its training system have become increasingly popular. In the society, many spiritual groups are deepening or doing professional yoga training packages included Ananda Marga, Yoga Seger Oger, Hatha Yoga, Sai Baba, Krsna Balaram, Brahma Kumaris, Yoga Marga Rahayu. Yoga is also very popular at the university. Yoga is one of the UKM-Yoga (Student Activity Unit) that has its stewardship, like UKM-Yoga in the University of Hindu Indonesia Denpasar and UKMYoga in the Insitute of Hindu Dharma Denpasar. In several pasraman (non-formal schools), Yoga Asana training, especially, Surya Namaskara is an activity that must be done by every bhakta (students), unlike Pasraman Seruling Dewata, Pasraman Sri Nahhuna Dhantha, and Pasraman Sri Jagat Amertham.

Related to the above description, there are two problems formulated in the present study: 1) how is the series of Surya Namaskara movement exhibited by Pasraman Sri Jagat Amertham devotees, Bitra Village, Gianyar Regency and the students in UKM Yoga Marga Rahayu in the University of Hindu Indonesia Denpasar. 2) What are the benefits felt by the students of the Pasraman Sri Jagat Amertham, Bitra Village, Gianyar Regency, and UKM Yoga Marga Rahayu in the University of Hindu Indonesia Denpasar on their physical health?

\section{Research Method}

\subsection{Data Collection}

a. Observation

An observation is a research or systematic and planned observation that is intended for obtaining a data that is controlled by its validity and reliability (Alwasilah, 2003: 211). Syaodih (2006: 220) stated that an observation is a technique or the way to collect a data by observing on ongoing activities. Bungin (2007: 115) stated an observation is a method of the data collection used to collect the research data through observation and sensing. Based on the above description, an observation in the present study is a direct observation of the yoga training (Surya Namaskara) conducted by Yoga Marga Rahayu (UKM-Yoga, University of Hindu Indonesia Denpasar) and Pasraman Sri Jagat Amertham. Direct observation is expected to obtain complete data and accurate.

b. Interview

An interview defines to get information orally from the informants, by talking face to face with someone (Koentjaraningrat, 1981: 162). According to Mulyana (2001: 180), an interview is a communication form between two people, involving someone who wants to obtain information from others by asking questions, based on a certain goal. It is the outline can be divided into two, i.e., unstructured interviews and structured interviews.

The researcher used unstructured interview techniques in the present research. It means that the interview is focused on yoga participants who do the training on Yoga Marga Rahayu. The question is not only conveyed in Indonesian but also carried out in the local language (Balinese languages). It is conducted. Therefore, the interview is casually done, not feel a formality. Thus, the interviewee can be free and comfortable in expressing all the ideas and feelings.

\subsection{Data Analysis}

a. Description

According to the data type of the research, that is a qualitative data. Therefore, the data analysis is conducted by a qualitative analysis which is descriptive or paraphrases. The description is one of discourse or rhetoric forms illustrated by describing the actual state or real state what is seen in a certain circumstance (Keraf, 2001: 3). The Ministry of National Education (2008: 320) stated that the description is the exploration or description in clear words and detail. Based on the above explanation, the description in this research is explore or description on the lexicons about the series of Surya

Wirawan, I. (2018). Surya Namaskara Benefits for Physical Health. International Journal Of Social Sciences And Humanities (IJSSH), 2(1), 43-55. doi:10.29332/ijssh.v2n1.78 
Namaskara movement, the relationship between Surya Namaskara with physical health development, and public response to Surya Namaskara in physical health development for the society.

b. Interpretative

The data analysis is used an interpretive method relies on the interpretation or illustration by the researcher. Ratna (2004: 45) stated that in the literature and philosophy of the interpretation in accordance with the hermeneutics and qualitative methods. According to Geertz (1992: 30), an interpretative is a way of adjusting (self-validating) or as an endorsed with surprises that are considered advanced from others who explain it. The interpretation activities require the breadth of the interpreter's intellectual insight into the object to be interpreted.

Regarding the above description, the interpretation is applied in this research is as a step to explain the series of Surya Namaskara movement, related to developing physical health, and society response, especially, yoga activist in two research locations.

\title{
3. Results and Analysis
}

\subsection{Praying before Surya Namaskara training}

Surya Namaskara is a training system passed down of the sages in the Vedic era, is inseparable from yoga asana. It is a tribute to the God of Sun as a life source through several movements or a dynamic posture. Yasa, et al. (tt: 105-152) stated that the three series of Surya Namaskara movements, i.e. Surya Namaskara Seri A, Surya Namaskara Seri B, and Surya Namaskara Seri C. Each series has different asana and asana repetition. Seri $A$ (series) consists of fourteen dynamic moves, Seri B series consists of twelve dynamic moves, and Seri $C$ consists of twenty-four dynamic moves. Among the three series of Surya Namaskara movements, the most popularly performed by yoga activists is Surya Namaskara Seri B movement, and this is the main subject in the present article.

Surya Namaskara training is conducted based on several stages commonly performed by yoga activists. Yoga Asana in the contest organized by the Ministry of Religious Affairs of Bali Province in 2016 participants are required stated that the prayers of Mantra Gayatri, Mrtynjaya, Maha Mrtyunjaya, and Guru. The Directorate General of Hindu Society Guidance (2013: 58) stated that is to start the Yoga Asana contest implementing of praying for Mantra Gayatri, Mrtynjaya, Maha Mrtyunjaya. However, in the Pesraman Sri Jagat Amertham and Yoga Marga Rahayu only use the Gayatri Mantra prayer which is repeated three times and chant the pranawa OM five times. It is intended to ask guidance, advisement, and protection to the Mother who as a source of love and clean five layers of the yoga trainers body, i.e., Panca Maya Kosa. The praying is as follows.

\author{
Sanskrit: \\ Om bhur bvah svah \\ Tat savitur varenyem \\ Bhargo devasya dhimahi \\ Dhiyo yo nah pracodayat \\ Indonesian translation: \\ Kita memusatkan pikiran kepada kemuliaan dan kecemerlangan \\ Hyang Widhi, semoga Ia berikan semangat pikiran kita. \\ English translation: \\ We focus on our minds for the glory and brilliance \\ God, may God give the spirit for our mind.
}

\subsection{Stretching}

a. Sitting Position

The legs are straightened forward, and the feet soles are pushed forward, both hands above the knee and set the breath comfortably. Hold this position up to eight times of counting. Then, pull the feet sole toward the back, and hold the position up to eight times of counting. After that, proceed with rotating 
both ankles to the left and right at the same time. It is followed by placing the left leg behind the groin of the right leg and try to keep the knee on the floor. Pull your knees up to your chest with your left hand, while your right-hand sticks your feet to keep them from moving, and push back your legs downwards. Do it eight times. Repeat with the other one of the foot.

b. Standing Position

The stretching in a standing position is begun with a take look to the right and the left. Then pull the head to the left with the left hand until feels the contraction in the neck, and vice versa, followed by a movement to look up, down and the end turning the head to the right and left. All is done eight times. This is to stretch the muscles in the neck. After that, proceed with stretching on the muscles of the hands, chest, and legs. Stretching on the hands and chest is done by straightening the right hand to the left and being pulled by the left hand, and vice versa. Then, straighten both hands up, bend your right hand and elbow right hand pulled by the left hand until right-hand palm stuck at the back. Stretching the legs, by lifting the right leg and being embraced by the both hands, keeping as close as possible to the chest, pulling the right leg back until the legs attach to the buttocks, and point the right foot forward, lift the knee slightly high and pull the ankle as close as possible to stomach. Hold on for eight times.

\subsection{Surya Namaskara}

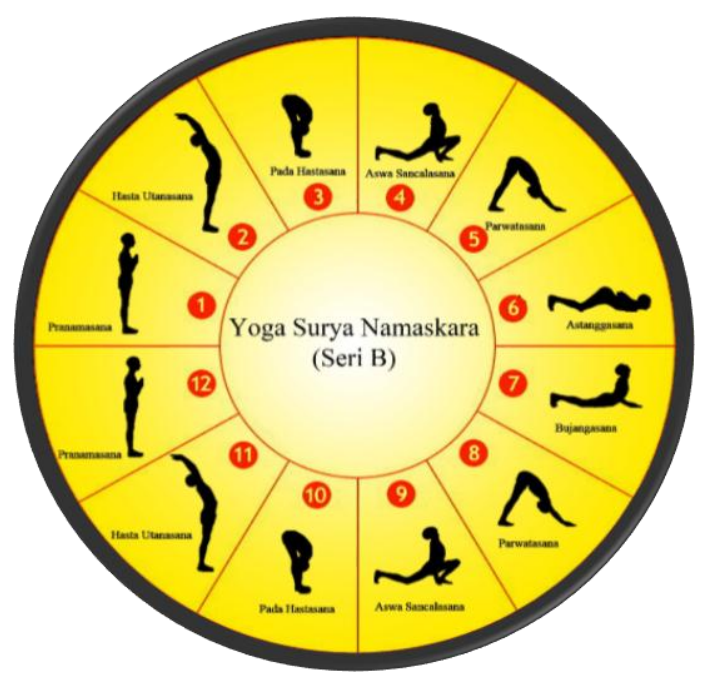

Description:

1. Pranamasana

Giving calm in concentrating, keep your breathing calm, orderly and as comfortable as possible.

2. Hasta Uttanasana

Stretch the contents of the abdominal cavity and open the entire lung chamber, inhale as both hands are lifted up and pulled back slightly

3. Padahastasana

Massaging the organs related to digestive organs and back leg muscles and reducing fat in the abdomen, exhale until empty stomach when bending body.

4. Aswa Sancalanasana

Massaging the abdominal organs, urinary tract, and improve its function and balance the nerves. This position is to sigh.

5. Parwatasana

Massaging and strengthening the nerves and muscles in both arms and legs, flex the spine, and blood circulation. Exhale.

Wirawan, I. (2018). Surya Namaskara Benefits for Physical Health. International Journal Of Social Sciences And Humanities (IJSSH), 2(1), 43-55. doi:10.29332/ijssh.v2n1.78 
6. Astangasana

Massaging and strengthening the chest muscles and leg muscles and arms. Hold your breath in a blank state.

\section{Bhujangasana}

Stretching and strengthening the spine, massage the back muscles, and melt the fat in the abdomen. Breathe deeply as you lift your body up. The next is a movement that is repeated up to the attitude pranamasana.

\subsection{Surya Namaskara benefits perceived by yoga participants on physical health}

Surya Namaskara is an important technique in a series of yoga training. It is a versatile "tool" and is very powerful in performing therapy on the human organs (Satyananda, 2002: 86). Flexibility (asana/gestures) and a fore in the way of its application (pranayama/though breath and concentration) will greatly affect the benefits generated to get a healthy and strong life. It is noticed right by yoga practitioners in Yoga Marga Rahayu and Peraman Sri Jagat Amertham training when practicing Surya Namaskara (interviewed with Ni Putu Mia Kesuma Dewi on July 22nd, 2016 and I Made Rupet on July 23rd, 2016).

Surya Namaskara is a powerful way to eradicate some diseases related to the human physiology, for it should be used wisely and under the guidance of the yoga skills. The healing process through Surya Namaskara practice is not felt in a short time, but gradually or slowly. Buanadjaya (1995: 70) stated that to get maximum benefit from yoga training or Surya Namaskara should be 1) the exercise purpose is solely to develop a healthy quality of life, which is in accordance with the human nature as established by the God. 2) The practice is done with the infinite gratitude of the God's grace that we are to be the Supreme Being, as human beings, therefore, the social value (purity of life) is able to give the insight of how great the God created us. How small is our strength, if it is compared to the God's omnipotence. 3) Practice diligently, patiently do not want to get results, due to yoga (Surya Namaskara) desire must be adapted to the human nature determined by the God. This is similar to a suggestion by Maharsi Patanjali (in Yasa, et al., 2011: 8788) "abhyasa wairagyabhyam tan nirodhah" which means a mind control should be done in the abhyasa 'discipline, careful, sustainable, and wairagya free, without binding to an action or unbounded worldly ambitions'.

Based on the above description, can be holistically presented about the benefits perceived by the participants from the routine does Surya Namaskara movement to the organ system or the human physical health.

a. Respiratory System

The human lungs consist of the spaces or parts. For normal breathing, the people rarely use all parts of the lungs. Most are used only the bottom while the top is rarely used. This situation causes the lungs to fill up with unused air piles, unlike carbon, dioxide, and gases containing toxins. This stockpiles slowly affect the respiratory system and other body systems. Surya Namaskara movement series, which use deep rhythmic breathing adapted to each movement will empty the lungs of unwanted air elements and replace them with new, cleaner, fresher, and oxygenated air. This can be conducted through the motion of urdhva vrakasana, hasta utthanasana, bhujangasana that is by drawing a deep breath, therefore, opening the chest cavity and padahastasana by breathing slowly that can be done through the nose is very strong cleansing breathing. All lung sacs are developed, then stimulated and cleaned. Thus, the lungs capacity when breathing will increase (Pujiastuti, 2008: 28). The automatic blood oxygen consists of increasing which provides adequate vitality and oxygen to the cells and tissues of the body and brain. A Lethargy will be quickly overcome, respiratory diseases unlike mucus buildup, tuberculosis, and others quickly removed (Satyananda, 2002: 98).

In related to the above explanation, I Made Rupet as the owner and manager of Pasraman Jagat Amertham stated since doing Surya Namaskara training in Pasraman Jagat Amertham his breathing was getting lighter and his body did not quickly accomplish. This can be felt when performing activities in Pasraman Sri Jagat Amertham. The distance between pasraman and residence is quite distant and the state of geography is very steep. For coming to pasraman can not use a motorcycle/car but can only be reached on foot, due to heading to pasraman location must go through many very steep stairs. It's unthinkable, it turns out every day, Mr. Made Rupet with his wife can do up and down stairs three to six 
times. This ability is not separated from the routine of conducting Surya Namaskara movement series programmed by Pasraman Sri Jagat Amertham (Interviewed, on August 22 ${ }^{\text {nd }}, 2016$ ).

b. Circulatory System

Surya Namaskara's exercise can improve our liver function, as well as body improvement or gymnastic exercise. The results can improve blood circulation and accelerate the elimination of toxic waste and provide fresh oxygen and nutrients to the cells. The blood buildup that stops on the spleen and other organs is removed, and the blood circulation is improved. The heart muscle strengthened, heart blood vessels and coronary arteries spur doubled, therefore, the circulatory increased and reduce the possibility of a heart attack. Coldness in the feet and hands, blood vessel disease due to slow blood circulation can also be healed, Satyananda (2002: 99).

Performing Surya Namaskara movement series based on patience, diligence and sincerity can also smooth the blood circulation in the lymph nodes that serve to maintain the balance of the body fluids. This can increase the immune system and increase the natural healing trap within. Padahastasana and Parvatasana help restore blood from the lower body to the heart, stretch the leg muscles and use the gravity force in reverse. The same term also stated by Pujiastuti (2008: 28), that through Surya Namaskara training can nourish or improve blood circulation throughout the body and brain as well as remove toxins from the body (detoxification).

Gusti Ngurah Putu Adi Kusuma and Eka Widyaningsih stated that they practiced yoga especially Surya Namaskara since they become a lecturer at the University of Hindu Indonesia. Surya Namaskara routinely practice conducted by UKM Yoga Marga Rahayu, the University of Hindu Indonesia according to a predetermined schedule that is every Saturday and Sunday. On Saturday training was done twice, i.e., from $06.30 \mathrm{am}$ until $08.00 \mathrm{am}$ and afternoon from $04.00 \mathrm{pm}$ until $06.00 \mathrm{pm}$. The exercise on Sunday is conducted from $04.00 \mathrm{pm}$ until $06.00 \mathrm{pm}$.

Regarding the routine exercise, many benefits are felt especially related to the physical health. Unlike, the students must be done some activities, e.g., lecturing activities with all the completeness and extracurricular of the student affairs. All of these activities require excellent body condition. This can be realized if the circulation of the blood or metabolism in the body goes well or smoothly. In order to keep or build the body to stay healthy, blood circulation smoothly or not tired, patient, diligent, and sincere conduct or practice Surya Namaskara according to the schedule set by UKM Yoga Marga Rahayu, University of Hindu Indonesia. He further stated since following Surya Namaskara training according to the schedule set, the laziness for the sluggish morning slope can be overcome (Interviewed on August $\left.11^{\text {th }}, 2016\right)$.

c. Digestive System

The alternating movements of stretching and emphasis on Surya Namaskara movements align the entire digestive system with a thorough massage on all abdominal cavities. Padahastasana and bhujangasana are very powerful asana to suppress and stimulate the abdominal organs. It does not only break down unnecessary substances, but it also increases the digestive flame, which increases appetite and speeds up the absorbing process of the juices. Good digestion is the beginning of the overall health. The undigested food will ferment in the stomach and intestines and become the gas that blocks the entire drain on the body. The problem of constipation and other stomach problems can be healed.

Nyoman Desi (interviewed on August $3^{\text {rd }}$, 2016) and Ni Putu Eka Yani (interviewed on September $7^{\text {th }}$, 2016) stated that before practicing Surya Namaskara movement series, the bowel movements were slightly disturbed. It rarely can defecate in the morning when just waking up. The circumstances like this, stomach feel uncomfortable, and the mind becomes chaotic. However, after practicing Surya Namaskara movement according to schedule in Pasraman Sri Jagat Amertham for Ni Putu Eka Yanti and training schedule on UKM Yoga Marga Rahayu for Nyoman Desi, then the bowel movement became smooth, therefore, physically felt fit.

Wirawan, I. (2018). Surya Namaskara Benefits for Physical Health. International Journal Of Social Sciences And Humanities (IJSSH), 2(1), 43-55. doi:10.29332/ijssh.v2n1.78 
d. Urine System

The kidney has a very important function in regulating water and salt in the human body, it also suppresses impurities from the blood and passes it through urine through the bladder. The kidney disorders can lead to an imbalance of the salt and increase the nitrogen content in the blood that causes the disease. Regarding Surya Namaskara training, bhujangasana, ashtanga namaskara, asva sancalanasana, and virabhadrasana of the spine and back muscles can be trained in a certain way to suppress and gentle massage on the kidneys. If the kidneys are not smooth or mild kidney disorders, there will be a tendency to form stones or the occurrence of the infection characterized by the urine color, it is rather dark, smells hard, often urine, and pain in the kidneys. Therefore, it is recommended that the Surya Namaskara training schedule reproduced and drank water as much as possible. This is intended to prevent precipitation or crystallization of the urinary tract.

Mr. Made Rupet (interviewed on July 26 ${ }^{\text {th }}, 2016$ ) stated before getting to know and Surya Namaskara often feels pain at waist and urination often disturbed. Though the food consumed included already selected, unlike not eating offal and also drinks that would disturb a urinary system. However, since practicing Surya Namaskara movement series and balanced drinking enough water, the pain gradually in the waist is getting heal and the urine can be smooth.

The same response was also stated by Nyoman Desi and Ni Putu Mia Kesuma Dewi (interviewed on September $\left.15^{\text {th }}, 2016\right)$. Since following an exercise program that is scheduled by UKM Yoga Marga Rahayu in UNHI, a urinary system channel is felt no obstacles or very smooth. However, from this interview, there are special benefits felt by them, which is related to femininity. Before practicing Surya Namaskara movements, they often experience very severe pain in the abdomen during menstruation, but after patience and diligently practicing Surya Namaskara the pain in the stomach when it gradually diminishes and eventually disappears.

e. Skin System

The skin is the outer most and the largest part of the human body. The skin also unites on our bodies organs, regulates body temperature, and also removes the body's toxins through sweat. If the blood circulation in our body smoothly, the toxins accumulation in the blood, will come out through the skin in the ulcers form, red spots, and acne, unpleasant odors and so on. This can be overcome by doing Surya Namaskara practice correctly and regularly based on patience, diligence, and sincerity to do it.

Eka Widyaningsih stated that before doing the routine, Surya Namaskara movement exercises often experience skin disorders, unlike the red spots appear on the skin and very itchy. In addition, it has also undergone surgery due to a severe boil. However, at following the activities of yoga and Surya Namaskara training conducted by UKM Yoga gradually all the disorders related to the skin can be overcome. Giving the benefits gained from Surya Namaskara practice very much in particular related to physical health, then Eka Widyaningsih wants to deepen the Surya Namaskara movements. From her persistence, she now becomes one of the yoga instructors at UKM Yoga Marga Rahayu in the University of Hindu Indonesia (interviewed on September $8^{\text {th }}, 2016$ ).

Surya Namaskara exercise properly and steady in the morning will get the sweat out, improve circulation, and encourage the toxins reduction through the digestive and urinary system. All disorders that occur in the skin as mentioned above can be cured. Likewise, when Surya Namaskara practice in the morning while facing the sunrise, automatic sun-emitted ultraviolet rays will be absorbed by the skin. The ultraviolet from the sun consists of vitamin D that is very good for the skin health.

\section{f. Nerve System}

The asana movement series are found in Surya Namskara serves to stretch the spine. Satyananda (2002: 102) stated that if Surya Namaskara is systematically conducted to the maximum limit can stimulate the circulation in the spine and all the nerve tissue in the spine. The nerve system in the spine consists of two parts, namely voluntary and involuntary. Those nerve systems regulate the body functions that are under conscious control, unlike the major and unconscious muscle movements included heart rate, breathing, and glandular secretions. The involuntary system consists of two subsystems, i.e., sympathetic and parasympathetic. Buanadjaya (1995: 76) call it in the term of simpaticus and parasimpaticus. 
The nervous system of the simpaticus and parasimpaticus are the autonomous or autonomic nervous system sections located on the left and right side of the spinal cord. It autonomously works (independent) and affects the internal organs work, including heart, lungs, liver, kidney, spleen, and others (Buanadjaya 1995: 76). The working balance both signifies that our bodies are healthy. However, there is a tendency in the modern humans that these systems do not work in balance or harmony (Satyananda, 2002: 103).

When the interview was conducted (on August 24th 2016 and September $3^{\text {rd }}, 2016$ ), from some informants; Ni Putu Eka Yanti, I Made Rupet, Putu Suastika, I Gusti Ngurah Putu Adi Kesuma, Ni Putu Mia Kesuma Dewi, Nyoman Desi, and Eka Widyaningsih stated that doing Surya Namaskara rhythm movement with patience, perseverance, and sincerity will make the mind calm and peace and mastering excellent body resistance. This is felt after so long undergoing yoga training, especially, Surya Namaskara. Therefore, it is very emphasized, to get the benefits in Surya Namaskara training should be instilled ourself, that is patient, diligent, and sincere do it.

g. Endocrine gland system

The endocrine glands are the most important and mysterious system for all systems. The endocrine gland consists of including pituitary gland, pineal gland, thyroid gland, parathyroid gland, thymus gland, adrenal gland, and gonads gland. The gonads gland is divided into two, i.e., female-ovaries in women to form eggs and male-testes in males for sperm improve (Satyananda, 2002: 418). The glands play a very important role in coordinating all physiological processes. The main function of the endocrine glands is to produce and secrete hormones. The chemical elements released into the bloodstream are circulated throughout the body and are responsible for a certain organ. This hormone acts as a mover, other organ stimulants to perform their respective functions in a balanced way (Satyananda, 2002: 104). In order to maintain the balance of the endocrine system, patience, perseverance, tranquility, and steadiness of Surya Namaskara training is one powerful enough way. This means that all movements consisted in Surya Namaskara can maintain the balance of the endocrine system gland. Therefore, yoga trainers should pay attention to asana (body movement), pranayama (breathing) and prthyahara (concentration) in conducting the Surya Namaskara movement series. (Interviewed with Eka Widyastuti on August 20, 2016, and Mrs. Ni Putu Eka Yanti on August $\left.24^{\text {th }}, 2016\right)$

\section{Conclusion}

Based on the above description and explanation, some conclusion is drawn as follow:

1) Surya Namaskara is a training system inherited by the sages in Vedas era, which is inseparable from yoga asana. Surya Namaskara is a tribute devoted to the God of Sun as a life source through the sequence of asana performed vinyasa 'flowing, dynamic.' Surya Namaskara practicing consisted of several asana followed by attraction, breath, and concentration. Starting Surya Namaskara training is done a praying. The training in Yoga Marga Rahayu and Pesraman Sri Jagat Amerthan use Gayatri Mantram that is repeated three times and pronounced pranawa OM three times. After that, the movements are followed by pavanamuktasana movement or stretching, Surya Namaskara and the end by savasana.

2) Steady, patient, diligent and sincere is to exercise the Surya Namaskara movement series can balance the system of the internal organs (human) primarily related to the respiratory system, circulatory system, digestive system, urinary or urine system, skin system, brain system, and endocrine system. The endocrine glands include the pituitary gland, pineal gland, thyroid gland, parathyroid gland, thymus gland, adrenal gland, and gonads gland. Regarding the internal organs balance, the healthy will always be physically or mentally as well as become calm and peaceful.

\section{Acknowledgements}

My deep and sincere gratitude were presented to God for having granted me the ability and the opportunity to complete this paper. As well as, I have much appreciated to my friends for their support, suggestion, contribution in finishing this research. I would like thank to Suryasa that has given me good

Wirawan, I. (2018). Surya Namaskara Benefits for Physical Health. International Journal Of Social Sciences And Humanities (IJSSH), 2(1), 43-55. doi:10.29332/ijssh.v2n1.78 
advisement. Last but not least, I dedicated my dreadful thank to my friend who those as editor in IJCU, IJMRA, SKIREC, Euro Asia as well as ScienceScholar who has reviewed and approved this study to be published. 


\section{References}

1. Arikunto, S. (2002). Metode penelitian. Jakarta: Rineka Cipta, 89-71.

View in (Google Scholar)

2. Belloc, N. B., \& Breslow, L. (1972). Relationship of physical health status and health practices. Preventive medicine, 1(3), 409-421.

View in (Google Scholar)

3. Billaiya, R., Jain, A., Agarwal, R., \& Jain, P. (2017). Introduction about Child Health Status in India. International Journal of Health Sciences (IJHS), 1(1), 12-22.

View in (Google Scholar)

4. Brahman, I. M. A. (2017). KORELASI AJARAN CADU SAKTI DENGAN CATUR YOGA. VIDYA SAMHITA, 3(2).

View in (Google Scholar)

5. Bungin, B. (2006). Sosiologi komunikasi: teori, paradigma, dan diskursus teknologi komunikasi di masyarakat. Jakarta: Kencana Prenada Media Group, 24-25.

View in (Google Scholar)

6. Campbell, J. C. (2002). Health consequences of intimate partner violence. The lancet, 359(9314), 13311336.

View in (Google Scholar)

7. Campbell, J. C., \& Lewandowski, L. A. (1997). Mental and physical health effects of intimate partner violence on women and children. Psychiatric Clinics, 20(2), 353-374.

View in (Google Scholar)

8. Coker, A. L., Davis, K. E., Arias, I., Desai, S., Sanderson, M., Brandt, H. M., \& Smith, P. H. (2002). Physical and mental health effects of intimate partner violence for men and women. American journal of preventive medicine, 23(4), 260-268.

View in (Google Scholar)

9. Dayuh, I. N. (2016). PENGETAHUAN SPIRITUAL YOGA. Jurnal Penjaminan Mutu, 1(2), 79-90. View in (Google Scholar)

10. Devi, S. (1957). Wrhaspati-tattwa: An old Javanese philosophical text. Internat. Acad. of Indian Culture. View in (Google Scholar)

11. Djam'an Satori, A. K. (2010). Metode Penelitian Kualitatif. Alfabeta, Bandung. .

View in (Google Scholar)

12. Esterling, B. A., L'Abate, L., Murray, E. J., \& Pennebaker, J. W. (1999). Empirical foundations for writing in prevention and psychotherapy: Mental and physical health outcomes. Clinical psychology review, 19(1), 7996.

View in (Google Scholar)

Wirawan, I. (2018). Surya Namaskara Benefits for Physical Health. International Journal Of Social Sciences And

Humanities (IJSSH), 2(1), 43-55. doi:10.29332/ijssh.v2n1.78 
13. Hakim, A. Neo-Tai Chi. VisiMedia.

View in (Google Scholar)

14. Indonesia, T. R. K. B. (2008). Kamus Bahasa Indonesia. Jakarta: Pusat Bahasa Departemen Pendidikan Nasional.

View in (Google Scholar)

15. Kusumayanti, G. D., \& Dewantari, N. M. (2017). The Influence of Low Purine Diet and Physical Activity on Changing of Uric Acid Levels in Hyperuricemia. International Journal of Health Sciences (IJHS), 1(3), 1-9. View in (Google Scholar)

16. Mustika, I. W., \& Harini, G. A. (2017). Increasing Education of Family Support for Decreasing Depression Level towards Elderly. International Journal of Health Sciences (IJHS), 1(3), 10-16.

View in (Google Scholar)

17.Pajak, D. J. (2012). Peraturan Direktur Jenderal Pajak Nomor PER-15/PJ/2012 tentang Perubahan Peraturan Direktur Jenderal Pajak Nomor PER-33/PJ/2011 tentang Badan/Lembaga yang dibentuk atau disahkan oleh Pemerintah yang ditetapkan sebagai Penerima Zakat atau Sumbangan Keagamaan yang sifatnya wajib yang dapat dikurangkan dari Penghasilan Bruto.

View in (Google Scholar)

18. Prastika, N. (2017). YOGA SASTRA Laku Mistik Balian Usada Bali. JURNAL ILMU AGAMA DAN KEBUDAYAAN, 17(02).

View in (Google Scholar)

19. Punyatmadja, O. I. B. (1994). Cilakrama. Denpasar: Upada Sastra.

View in (Google Scholar)

20. Ramaiah, S. (2003). Kecemasan, bagaimana mengatasi penyebabnya. Yayasan Obor Indonesia.

View in (Google Scholar)

21. Ratna, I. N. K. (2004). Teori, metode \& teknik penelitan sastra: dari strukturalisme hingga postrukturalisme: perspektif wacana naratif. Pustaka Pelajar.

View in (Google Scholar)

22. Rippentrop, A. E., Altmaier, E. M., Chen, J. J., Found, E. M., \& Keffala, V. J. (2005). The relationship between religion/spirituality and physical health, mental health, and pain in a chronic pain population. Pain, 116(3), 311-321.

View in (Google Scholar)

23. Saraswati, S. S., \& Hiti, J. K. (1996). Asana pranayama mudra bandha. Bihar, India: Yoga Publications Trust. View in (Google Scholar)

24. Sindhu, P. (2015). Panduan lengkap yoga: untuk hidup sehat dan seimbang. Mizan Qanita.

View in (Google Scholar) 
25. Sudharta, T. R. (1993). Slokāntara: untaian ajaran etika. Upada Sastra.

View in (Google Scholar)

26. Suiraoka, I. P., Duarsa, D. P. P., Wirawan, I. D. N., \& Bakta, I. M. (2017). Perception of Parents, Teachers, and Nutritionist on Childhood Obesity and Barriers to Healthy Behavior: A Phenomenological Study. International Journal of Health Sciences (IJHS), 1(2), 1-11.

View in (Google Scholar)

27. Suka Yasa, I Wayan, et al. (2006). Yoga: Marga Rahayu. Cetakan I. Denpasar: Widya Dharma bekerjasama dengan Tim Fakultas Ilmu Agama UNHI.

View in (PDF)

28. Sura, I Gde dan Suka Yasa, I.W. (2011). Samkhya-Yoga. Denpasar: Lembaga Penelitian UNHI.

View in (Google)

29. Wijaya, N. Apakah Agama Hindu Bali Modern Lahir dari Tantangan Pancasila dan Islam. Journal of Bali Studies, 4(1).

View in (Google Scholar)

\section{Biography of Author}

\begin{tabular}{|l|l|}
\hline I Gusti Bagus Wirawan is a lecturer in the University of Hindu Indonesia. He \\
graduated from the faculty of arts at Udayana University. He finished her master \\
degree in religion and culture in the University of Hindu Indonesia. He completed \\
his doctoral degree as well as of religion and culture in the University of Hindu \\
Indonesia. He lives at Jalan Sangalangit, Tembau, Penatih, East Denpasar. His \\
phone number +6281558017350 \\
Email address: ajikwirawan@gmail.com
\end{tabular}

Wirawan, I. (2018). Surya Namaskara Benefits for Physical Health. International Journal Of Social Sciences And Humanities (IJSSH), 2(1), 43-55. doi:10.29332/ijssh.v2n1.78 